\title{
The effect of stage of lactation on daily milk yield, and milk fat and protein content in Tsigai and Improved Valachian ewes
}

doi: $10.15567 /$ mljekarstvo.2015.0107

\author{
Marta Oravcovál ${ }^{1 *}$, Milan Margetín ${ }^{1,2}$, Vladimír Tančin ${ }^{1,2}$ \\ ${ }^{1}$ National Agricultural and Food Centre, Research Institute for Animal Production Nitra, \\ Hlohovecká 2, 95141 Lužianky, Slovak Republic \\ ${ }^{2}$ Slovak University of Agriculture in Nitra, Tr. A. Hlinku 2, 94976 Nitra, Slovak Republic
}

Received - Prispjelo: 09.12.2013. Accepted - Prihvaćeno: 16.01.2015.

\begin{abstract}
The objective of this study was to analyse the effect of stage of lactation on daily milk yield, and milk fat and protein content in Tsigai and Improved Valachian ewes. Breed lactation curves for daily milk yield, and milk fat and protein content were modelled as a sub-model of the three-trait animal model based on repeated test-day records that were collected by the Breeding Services of the Slovak Republic between 1995 and 2010. Data included 188403 (Tsigai) and 352094 (Improved Valachian) ewe's performance records. Pedigree file included 35484 (Tsigai) and 66994 (Improved Valachian) animals with genetic ties to ewes with milk performance data. The fixed part of the model included parity, litter size and stage of lactation. The effect of days in milk (i.e. stage of lactation) was fitted using Ali and Schaeffer lactation curve. The random part of the model included flock-test day effect, direct additive genetic effect, and permanent environmental effect of ewe nested within lactation. Due to limited number of test-day records in the first and the eighth month of lactation and related difficulties in modelling milk traits in these phases of lactation, the lactation curves were plotted between days 30 and 210. During lactation period the daily milk yield curves were decreasing, while milk fat and protein content were increasing. Because of higher changes at the beginning of lactation balanced with higher changes at the end of lactation in Tsigai and smaller changes at the beginning of lactation balanced with smaller changes at the end of lactation in Improved Valachian, 150d milk yield and average milk fat and protein content were almost the same in both breeds.
\end{abstract}

Key words: dairy ewes, lactation curves, daily milk yield, milk fat and protein content

\section{Introduction}

Tsigai and Improved Valachian are the most spread sheep breeds in Slovakia. Both are multi-purpose breeds (Krupová et al., 2009), well adapted to local climate and environment. Tsigai is one of the oldest native breeds in areas from 500 to 800 $\mathrm{m}$ above sea level, mostly in the semi-extensive production system (Krupová et al., 2009), while improved Valachian is mostly kept in mountains and foothill areas more than $800 \mathrm{~m}$ above sea level in the extensive/semi-extensive production system. The breed was created with crossing of former Valachian with Texel, Lincoln Longwool and Leicester Longwool, and was recognised in 1982 (Oravcová et al., 2006). The income from breeds is almost equally distributed between milk (cheese) production and production of offspring for slaughter as young animals (Oravcová and Peškovičová, 2008), while wool is just a marginal product.

The importance of ewe's milk market is increasing in Slovakia. Therefore, there is growing 
interest in increase of milk yield and efficiency of milking. Studies analyzing the factors affecting ewe's milk yield and milk composition (Margetín et al., 1996; Čapistrák et al., 2005; Tančin et al., 2011; Antonič et al., 2013) such as breed, age at lambing, parity, litter size as well as studies estimating lactation curves (Oravcová et al., 2006, 2007) were performed. Among factors that affect variation of daily milk yield, milk fat and protein content, the effect of stage of lactation was reported important by Gonzalo et al. (1994), Pavic et al. (2002), Komprej et al. (2012). Various lactation curves based on Wood (1967), Cobby and Le Du (1978), Wilmink (1987) model were firstly used in cattle. Moreover, additional models such as Ali and Schaeffer (1987), Morant and Gnanasakthy (1987), Guo and Swalwe (1995) were developed. Their suitability in ewes was tested by Bilgin et al. (2010).

The first study aimed at quantification of direct additive genetic effect and permanent environmental effect of ewe (Oravcová et al., 2005, 2008) showed that these effects are important sources of variability of milk traits and should be taken into account when fitting lactation curves to milk traits data. Heritabilities of milk traits were estimated between 0.12 and 0.19 , and between 0.06 and 0.10 in Tsigai and Improved Valachian breeds, respectively. Variance ratios of permanent environmental effect of ewe were between 0.04 and 0.11 , and between 0.02 and 0.11 in Tsigai and Improved Valachian breeds, respectively. The highest variance ratio was found for flock test day effect: between 0.34 and 0.39 , and between 0.41 and 0.48 in Tsigai and Improved Valachian breeds, respectively. An influence of the effect of lactation stage which takes into account additional genetic and non-genetic (environmental) factors using the animal model has not been analyzed in Slovakia until now. Also, previous estimation of lactation curves in Slovak ewes considered flock-test day effect as fixed.

The objective of this study was to investigate the effect of stage of lactation on daily milk yield, and milk fat and protein content in Tsigai and Improved Valachian ewes taking into account additional fixed and random genetic and environmental factors affecting variability of milk traits. The number of test-day records considerably increased in recent years; therefore, changes in milk traits over time were also investigated.

\section{Material and methods}

Test-day records of daily milk yield, and milk fat and protein content were collected by the Breeding Services of the Slovak Republic between 1995 and 2010, following the AC method of ICAR guidelines. The AC method stands for corrected monthly test for evening/morning differences, taking into account the total volume of milk produced by the whole flock over the two milkings concerned (ICAR, 2011). Milk fat and protein content were determined using the automated infrared method and apparatus calibrated against known sample standards (Oravcová et al., 2007). The analysis of daily milk yield was based on 188403 (Tsigai) and 352094 (Improved Valachian) test-day records; at least three test-days per lactation and four flock-test-day measurements were required. Records with daily milk yield lower than $0.1 \mathrm{~kg}$ and higher than $3 \mathrm{~kg}$ as well as with milk fat and protein content outside the ranges from 2 to $15 \%$ and from 1 to $9 \%$ were deleted. Records for milk fat and protein content were less numerous than records for daily milk yield due to fact that test-day records with no measurements of milk fat and protein content are accepted in national and/or flock evaluation. In Tsigai and Improved Valachian, 167784 and 312829 test-day measurements of milk fat content and 167646 and 312913 test-day measurements of milk protein content were available. The distribution of test-day records of each breed over days in milk is given in Figure 1. The majority of test-day records occurred in the middle of lactation. The shape of distribution was found similar between breeds.

Since the number of test-day records considerably increased in recent years, Wilcoxon test as implemented in NPARIWAY procedure (SAS Inst. Inc., 2009) was used to investigate differences between daily milk yield, fat and protein content in early (1995-1999) and late period (2006-2010) within each breed.

Milk traits were analysed separately for each breed using the same three-trait animal model:

$$
Y=X \beta+Z_{f} f+Z_{a} a+Z_{p} p+e
$$

where

- $Y$ is the vector of observations of daily milk yield, and milk fat and protein content 


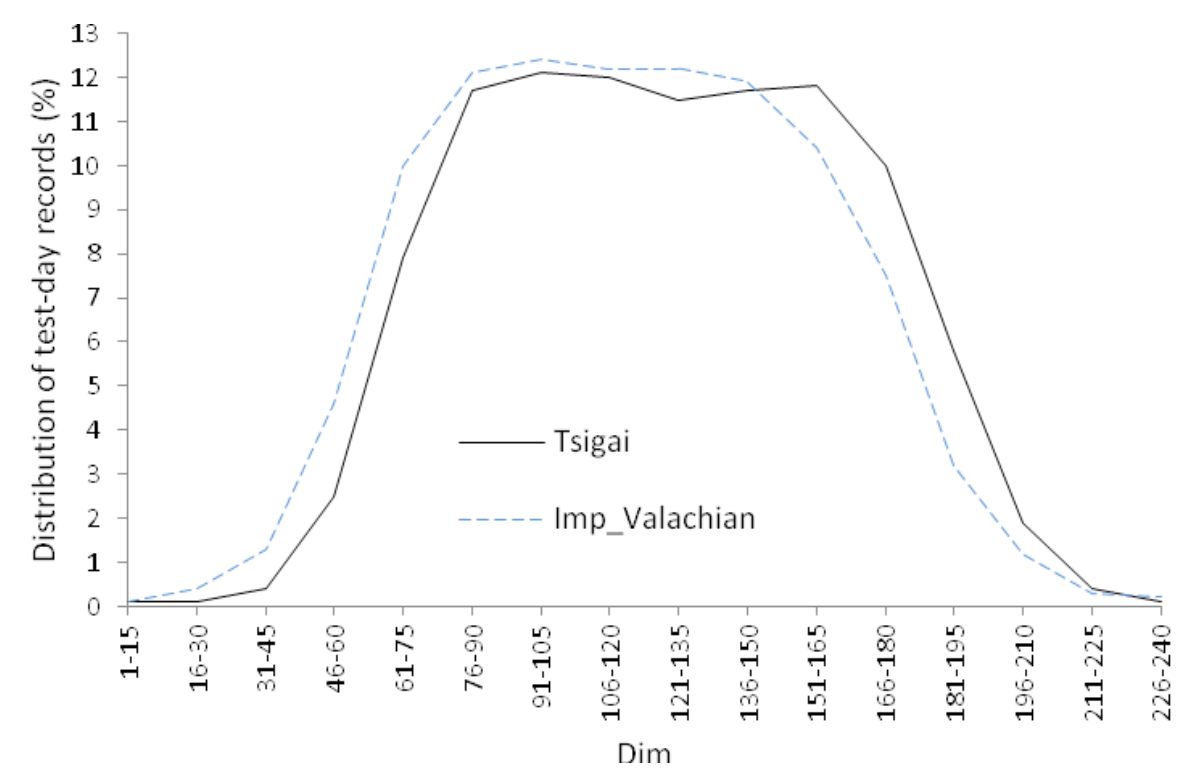

Figure 1. Distribution of test-day records (daily milk yield measurements) over days in milk in Tsigai and Improved Valachian breeds

- $\quad \beta$ is the vector of unknown parameters for fixed

- $X$ is the incidence matrix for fixed effects effects of parity, stage of lactation (i.e. days in milk) and litter size

- $f, a, p$ are the vectors of unknown parameters for flock-test day effect, direct additive genetic effect, and permanent environmental effect of - $Z_{f} Z_{a^{\prime}} Z_{p}$ are the incidence matrices for random flock-test day effect, direct additive genetic effect, and permanent environmental effect of ewe nested within lactation ewe nested within lactation

In scalar notation, the model can be presented as follows:

$$
y_{i j k l}=P_{i}+B_{j}+b_{1}\left(\frac{D I M_{i j k l}}{150}\right)+b_{2}\left(\frac{D I M_{i j k l}}{150}\right)^{2}+b_{\mathbf{3}} \ln \left(\frac{150}{D I M_{i j k l}}\right)+b_{4} \ln \left(\left(\frac{150}{D I M_{i j k l}}\right)\right)^{2}+f_{k}+a_{l}+p_{l i}+e_{i j k l}
$$

\section{where:}

- $y_{i j k l}$ is the observation of daily milk yield, and milk fat and protein content

- $\quad P_{i}$ is the effect of parity: first (1), second (2) and third and following parities $(3+), \sum_{i}^{3} P_{i}=0$

- $\quad B_{j}$ is the effect of litter size: one (1) and two and more lambs $(2+), \sum^{2} B_{j}=0$

- $\quad b_{1}$ to $b_{4}$ are the regression coefficients of Ali and Schaeffer (1987) lactation curve

- $D I M_{i j k l}$ are the days in milk involved as covariates in the model

- 150 is the constant which takes into account a shorter length of standardised lactation in ewes than in cows

- $f_{k}$ is the flock-test day effect with 1583 (Tsigai) and 2304 (Improved Valachian) levels

- $a_{l}$ is the direct additive genetic effect with 35484 (Tsigai) and 66994 (Improved Valachian) levels

- $\quad p_{l i}$ is the permanent effect of ewe nested within lactation with 46283 (Tsigai) and 87098 (Improved Valachian) levels

- $e_{i j k l}$ is the residual 
The fixed part of the model was analyzed using GLM (General Linear Model) procedure (SAS Inst. Inc., 2009) based on Least Squares Method. Covariance components were estimated using the REML (Restricted Maximum Likelihood) method as applied in VCE 6 (Groeneveld et al., 2010). The main effects were described in previous studies of Oravcová et al. (2005, 2006, 2007 and 2008). The model used here was aimed to estimated only one lactation curve for each trait in each breed (i.e. lactation curves were not assumed to differ in shape between parities), taking into account the random part of the model (i.e. direct additive genetic effect and permanent effect of ewe nested within lactation). The model did not employ less significant effects (i.e. age at lambing, number of milkings per day) considered earlier.

\section{Results}

The data structure showed the imbalanced frequency of test-day measurements in individual production years: an increase of about $66 \%$ of test-day records in late period (2006-2010) in comparison to early period (1995-1999) of milk performance testing was observed in Tsigai and Improved Valachian ewes. Also, monthly averages of daily milk yield, and milk fat and protein content during lactation differed in each breed between early and late period (Table 1). The lower daily milk yield ( 0.583 vs. $0.640 \mathrm{~kg}$ in Tsigai and 0.562 vs. $0.667 \mathrm{~kg}$ in Improved Valachian, respectively) and the higher milk fat content (8.22 vs. $7.29 \%$ in Tsigai and 7.92 vs. $7.51 \%$ in Improved Valachian, respectively) and milk protein content (6.01 vs. $5.86 \%$ in Tsigai and 5.81 vs. $5.82 \%$ in Improved Valachian, respectively) were found in early period. Regardless of breed, highest changes were found in daily milk yield and almost stable milk protein content was found. The average values of daily milk yield, and milk fat and protein content between two periods differed by 9 and $16 \%$, by 0.93 and 0.41 percentage points and by 0.15 and 0.01 percentage points in Tsigai and Improved Valachian breed, respectively. Daily milk yield was mainly decreasing from the first to the last month of lactation, whereas milk fat and protein content were mainly increasing. Standard deviations followed the pattern of month averages of daily milk yield, and milk fat and protein content (with an increasing number of days in milk these were predominantly decreasing for daily milk yield and increasing for milk fat and protein content).

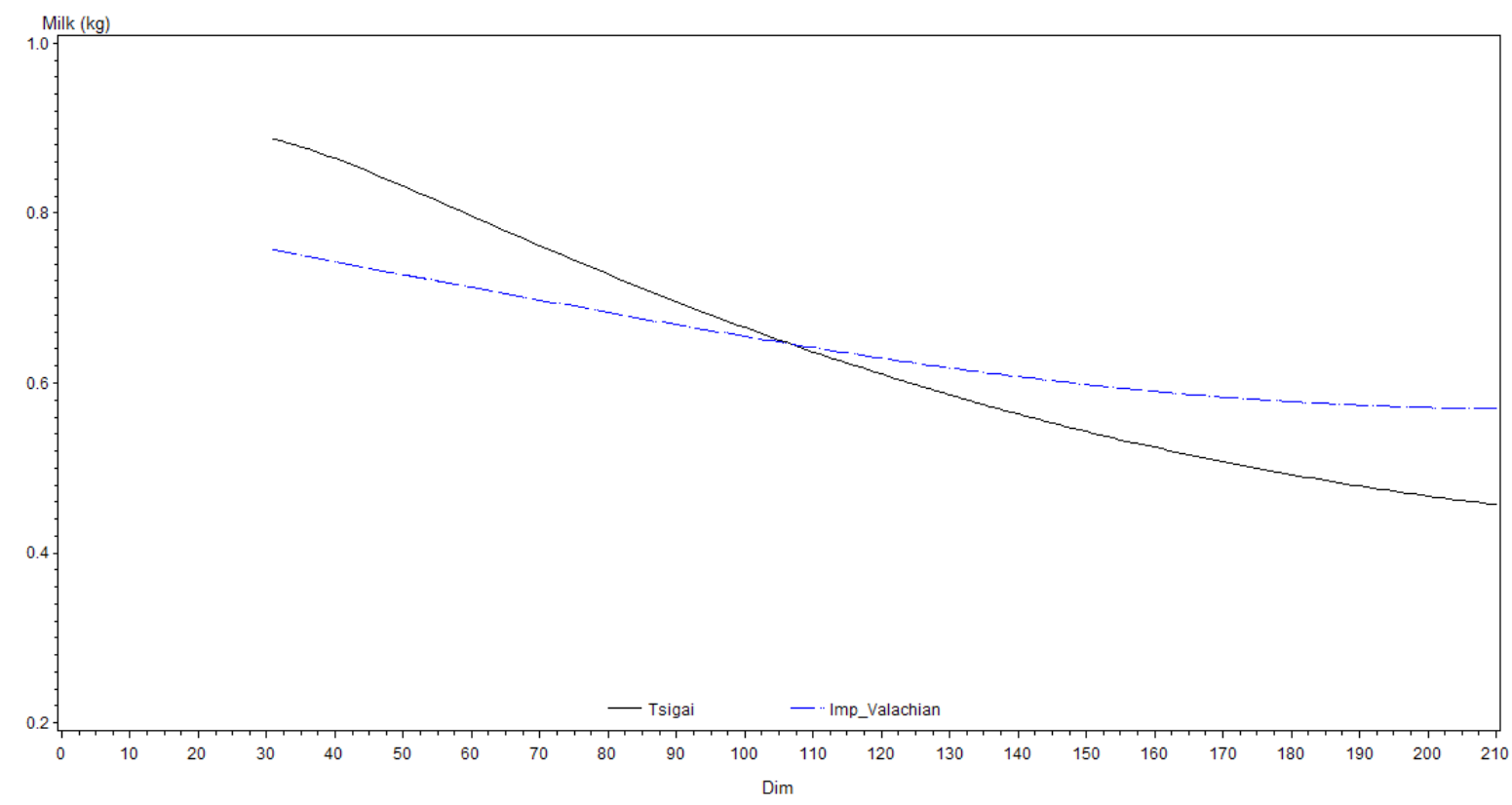

Figure 2. Changes of milk yield during lactation of Tsigai and Improved Valachian ewes 
Significant differences found in milk traits between early and late period (Wilcoxon test as implemented in NPARIWAY procedure SAS Inst. Inc., 2009), gave an opportunity to include data from latest years in the analysis and to re-estimate lactation curves in each breed.

Ali and Schaeffer (1987) lactation curves were used to model milk traits in dependence on days in milk (Figures 2 to 4 ). Due to limited number of test-day records in the first and the eighth month of lactation and related difficulties in modelling milk traits in these phases of lactation (see Oravcová et al., 2006, 2007 for comparisons), the lactation curves presented here were plotted between days 30 and 210. The lower persistency of milk yield during lactation was found in Tsigai breed (Figure 2): the lower daily milk yield was found at the beginning of lactation and the higher daily milk yield was found at the end of lactation in Improved Valachian breed. As a result of such pattern, 150d milk yield calculated by summarising daily milk yields estimated between days 50 and 200 was almost the same in both breeds i.e. about $96 \mathrm{~kg}$. The day 50 was chosen as a starting point since suckling period takes about 50 days on average and the day 200 was chosen as an ending point since only high productive flocks are milked and recorded in late lactation and most of ewes are dried off in the seventh month of lactation.

Table 1. Changes of daily milk yield, and milk fat and protein content by month of lactation in Tsigai and Improved Valachian breed

\begin{tabular}{|c|c|c|c|c|c|c|}
\hline \multirow{2}{*}{$\frac{\text { Breed }}{\text { Period/Month }}$} & \multicolumn{3}{|c|}{ Tsigai } & \multicolumn{3}{|c|}{ Improved Valachian } \\
\hline & $\begin{array}{c}\text { Daily milk } \\
\text { yield, kg } \\
\overline{\mathrm{x}} \pm \mathrm{s}\end{array}$ & $\begin{array}{c}\text { Fat, \% } \\
\bar{x} \pm s\end{array}$ & $\begin{array}{l}\text { Protein, \% } \\
\quad \bar{x} \pm s\end{array}$ & $\begin{array}{c}\text { Daily milk } \\
\text { yield, kg } \\
\overline{\mathrm{x}} \pm \mathrm{s}\end{array}$ & $\begin{array}{l}\text { Milk fat, } \% \\
\bar{x} \pm s\end{array}$ & $\begin{array}{c}\text { Milk protein, } \% \\
\overline{\mathrm{x}} \pm \mathrm{s}\end{array}$ \\
\hline \multicolumn{7}{|l|}{1995 to 1999} \\
\hline 1 & $1.066 \pm 0.413$ & $6.07 \pm 1.26$ & $5.28 \pm 0.31$ & $0.579 \pm 0.228$ & $7.47 \pm 1.38$ & $5.42 \pm 0.67$ \\
\hline 2 & $0.785 \pm 0.373$ & $6.94 \pm 1.44$ & $5.28 \pm 0.54$ & $0.614 \pm 0.292$ & $7.16 \pm 1.35$ & $5.36 \pm 0.60$ \\
\hline 3 & $0.711 \pm 0.322$ & $7.15 \pm 1.43$ & $5.56 \pm 0.59$ & $0.643 \pm 0.283$ & $7.16 \pm 1.42$ & $5.50 \pm 0.57$ \\
\hline 4 & $0.696 \pm 0.309$ & $7.69 \pm 1.37$ & $5.74 \pm 0.56$ & $0.643 \pm 0.258$ & $7.50 \pm 1.21$ & $5.64 \pm 0.55$ \\
\hline 5 & $0.547 \pm 0.254$ & $8.30 \pm 1.52$ & $5.86 \pm 0.59$ & $0.553 \pm 0.200$ & $7.97 \pm 1.36$ & $5.73 \pm 0.56$ \\
\hline 6 & $0.476 \pm 0.228$ & $8.85 \pm 1.71$ & $6.27 \pm 0.68$ & $0.451 \pm 0.159$ & $8.79 \pm 1.41$ & $6.10 \pm 0.62$ \\
\hline 7 & $0.410 \pm 0.196$ & $9.61 \pm 1.95$ & $6.92 \pm 0.79$ & $0.379 \pm 0.152$ & $9.37 \pm 1.52$ & $6.75 \pm 0.67$ \\
\hline 8 & $0.380 \pm 0.298$ & $9.94 \pm 2.22$ & $7.42 \pm 0.77$ & $0.406 \pm 0.144$ & $9.17 \pm 1.68$ & $7.11 \pm 0.64$ \\
\hline Total & $0.583 \pm 0.302$ & $8.22 \pm 1.82$ & $6.01 \pm 0.81$ & $0.562 \pm 0.248$ & $7.92 \pm 1.61$ & $5.81 \pm 0.71$ \\
\hline \multicolumn{7}{|l|}{2006 to 2010} \\
\hline 1 & $0.962 \pm 0.422$ & $5.44 \pm 1.37$ & $5.57 \pm 0.50$ & $0.874 \pm 0.467$ & $7.01 \pm 1.35$ & $5.12 \pm 0.53$ \\
\hline 2 & $0.788 \pm 0.339$ & $6.45 \pm 1.37$ & $5.47 \pm 0.52$ & $0.719 \pm 0.309$ & $6.97 \pm 1.14$ & $5.38 \pm 0.54$ \\
\hline 3 & $0.752 \pm 0.329$ & 6.621 .39 & $5.62 \pm 0.48$ & $0.724 \pm 0.276$ & $6.96 \pm 1.18$ & $5.65 \pm 0.48$ \\
\hline 4 & $0.718 \pm 0.319$ & $6.93 \pm 1.27$ & $5.74 \pm 0.46$ & $0.702 \pm 0.253$ & $7.14 \pm 1.21$ & $5.77 \pm 0.46$ \\
\hline 5 & $0.598 \pm 0.277$ & $7.51 \pm 1.39$ & $5.86 \pm 0.51$ & $0.627 \pm 0.224$ & $7.71 \pm 1.23$ & $5.81 \pm 0.51$ \\
\hline 6 & $0.517 \pm 0.250$ & $8.00 \pm 1.52$ & $6.17 \pm 0.59$ & $0.598 \pm 0.205$ & $8.23 \pm 1.24$ & $6.09 \pm 0.60$ \\
\hline 7 & $0.486 \pm 0.259$ & $8.29 \pm 1.46$ & $6.43 \pm 0.66$ & $0.617 \pm 0.203$ & $8.39 \pm 1.18$ & $6.39 \pm 0.63$ \\
\hline 8 & $0.414 \pm 0.185$ & $8.45 \pm 1.50$ & $7.17 \pm 0.69$ & $0.622 \pm 0.228$ & $7.81 \pm 1.20$ & $6.37 \pm 0.63$ \\
\hline Total & $0.640 \pm 0.311$ & $7.29 \pm 1.51$ & $5.86 \pm 0.58$ & $0.667 \pm 0.252$ & $7.51 \pm 1.31$ & $5.82 \pm 0.56$ \\
\hline Diff. & ++ & ++ & ++ & ++ & ++ & ++ \\
\hline
\end{tabular}

$\mathrm{N}$ : number of observations; $\overline{\mathrm{X}}$ - average; s - standard deviation

Diff. - differences between mean values of milk traits in period 1995-1999 vs. period 2006-2009; ${ }^{++}-\mathrm{p}<0.01$ 


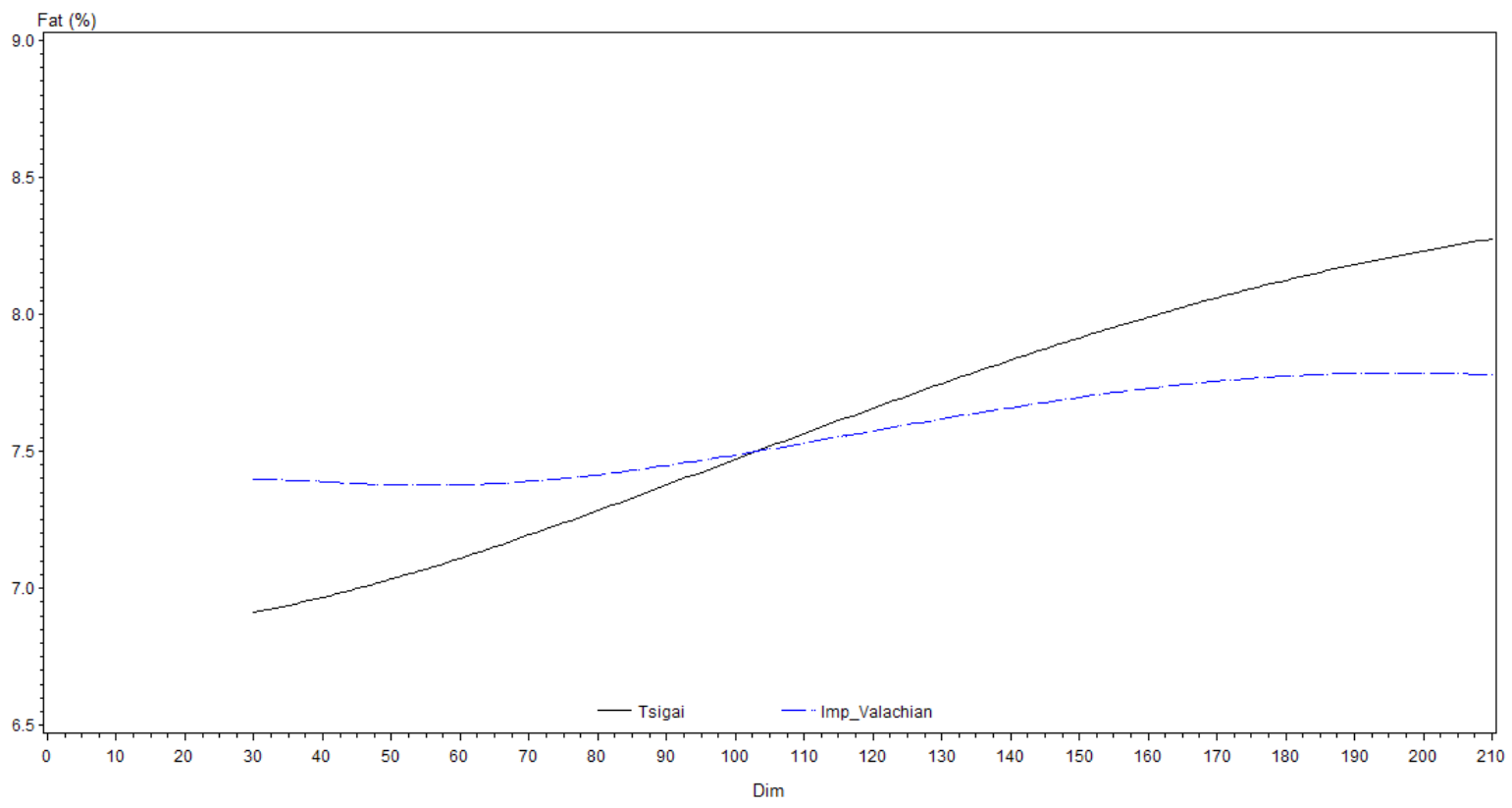

Figure 3. Changes of milk fat content during lactation of Tsigai and Improved Valachian ewes

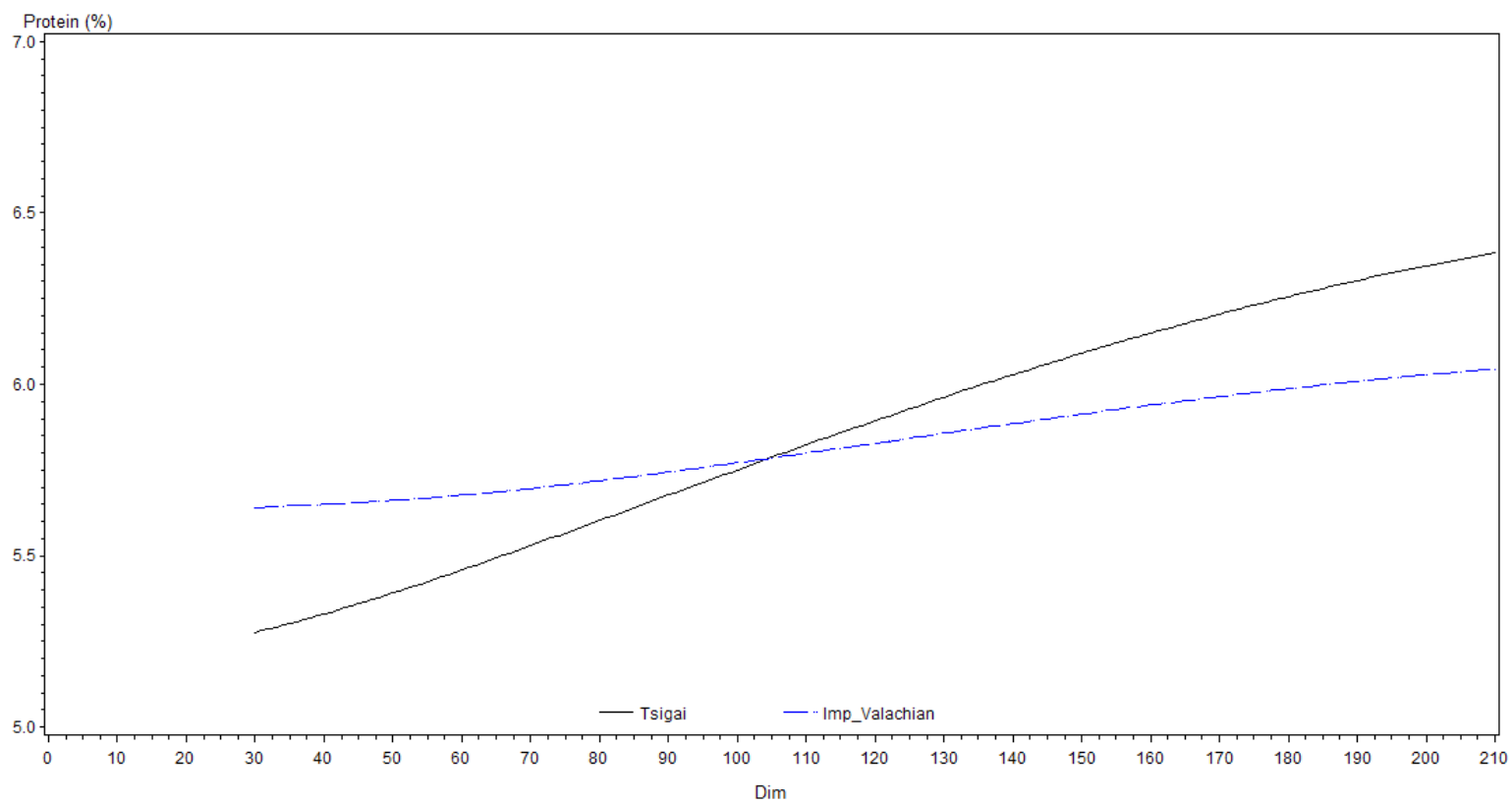

Figure 4. Changes of milk protein content during lactation of Tsigai and Improved Valachian ewes 
Changes of milk fat and protein content during lactation were similar in Tsigai and Improved Valachian ewes; milk fat and protein content between days 50 and 200 of lactation did not differ more than by 0.10 percentage points. Similarly to daily milk yield, changes of milk fat and protein content were found lower in Improved Valachian breed (Figures 3 and 4). In total, daily milk yield decreased by 44 and $21 \%$; milk fat content increased by 1.20 and 0.41 percentage points; milk protein content increased by 0.95 and 0.37 percentage points between days 50 and 200 of lactation in Tsigai and Improved Valachian.

\section{Discussion}

The number of ewes included in milk performance testing in Slovakia was gradually increased. There were 4162 (Tsigai) and 8102 (Improved Valachian) ewes recorded in early period (1995-1999), and 11500 (Tsigai) and 19651(Improved Valachian) ewes in late period (2006 to 2010). Daily milk yield, and milk fat and protein content found in both breeds and both periods fell in the range reported in literature (see Oravcová et al., 2006, 2007 for comparisons): daily milk yield was similar to the lower values of daily milk yield found in literature; milk fat and protein content were similar to the higher values of milk fat and protein content found in literature. An increase of daily milk yield between early and late period was accompanied with a decrease of milk fat and protein content in both breeds. This decrease indicates that nutritional value of ewe's milk, as milk fat and protein content is concerned, is changing to a lower extent. When breeders are willing to avoid the decrease of milk fat and protein content in future, selection will have to be aimed not only at increasing milk yield but also increasing milk composition.

In contrast to previous studies of Oravcová et al. (2006, 2007), coefficients of Ali and Schaeffer (1987) lactation curve were not considered nested within parities and only one lactation curve for each milk trait in each breed was estimated here. This approach appeared to describe milk traits according to stage of lactation sufficiently, though some limitations to describe the beginning and the end of lactation curves occurred. Lactation curve for daily milk yield showed the decreasing trend with an increasing number of days in milk. This shape was less visible in previous study of Oravcová et al. (2006) where no animal model was applied and almost stable or even slightly increasing daily milk yields at the end of lactation in both breeds were found. In comparison to Tsigai, smaller changes of milk traits were found during lactation in Improved Valachian (21 vs. 44 \%).

Based on comparisons between lactation curves, higher changes of milk traits during lactation, or similar to those in Tsigai, were reported in literature. For instance: Gonzalo et al. (1994) and Fuertés et al. (1998) found milk yield decreasing by $70 \%$ between days 45 and 150 of lactation in Churra ewes. Carta et al. (1995) reported the decrease of daily milk yield in Sarda breed by $65 \%$ between days 30 and 270 of lactation which corresponded to the decrease of daily milk yield about $30 \%$ between days 30 and 150 of lactation. Ruiz et al. (2000) reported the lower decrease of daily milk yield between days 50 and 160 of lactation (36\% as a result of the higher persistency) in the first parity Latxa ewes when comparing ewes of different parities.

Daily milk yield in multiparous Valle del Belice ewes decreased by $50 \%$ between days 50 and 225 of lactation (Cappio-Borlino et al., 1997); the decrease of daily milk yield was slightly lower in primiparous ewes. Daily milk yield in Boutsico breed decreased by $70 \%$ between days 24 and 248 of lactation (Kominakis et al., 2002). Komprej et al. (2012) found daily milk yield decreasing by 60 and $70 \%$ between days 45 and 150 of lactation in Improved Bovec and Bovec, respectively. Daily milk yield in Pag ewes decreased by 43 and $75 \%$ (ewes of South-West and North-East of Pag island were compared) between days 20 and 180 (Barać et al., 2012). Daily milk yield in Istrian ewes decreased by $41 \%$ between days 20 and 180 (Vrdoljak et al., 2012). Peralta-Lailson et al. (2005) found the decrease of daily milk yield between the beginning and the end of lactation varying from 62 to $78 \%$ in the varieties of Creole breed of Chiapas-Mexico.

The decrease of daily milk yield as lactation progressed was also referred by El-Saied et al. (1998) in their study on Churra ewes. Similarly to findings in this study, the increase of milk fat and protein during lactation (either the decrease of milk composition at the beginning of lactation was observed or not) was referred by Gonzalo et al. (1994), E1-Saied et al. (1998), Fuertés et al. (1998), Komprej et al. (2012). In Pag and Istrian ewes, the increase of milk fat and protein content during lactation was referred by Vrdoljak et al. (2012). 


\section{Conclusions}

The analysis showed that the effect of stage of lactation influenced variability of ewe's daily milk yield, and milk fat and protein content. Higher changes of milk traits during lactation were found in Tsigai. Nevertheless, 150d milk yield and average milk fat and protein content were almost the same in both breeds due to fact that higher changes at the beginning of lactation were balanced with higher changes in the end of lactation in Tsigai and smaller changes in the beginning of lactation were balanced with smaller changes at the end of lactation in Improved Valachian.

Since milk price is independent of amount of milk fat and protein content (the only requirement is to meet given minimal values), selection in Slovak sheep is aimed at increasing milk yield. Such selection is consequently accompanied with a decrease of milk fat and protein content as comparison of traits between early and late period of milk performance testing in Slovakia showed. When breeders are willing to avoid a further decrease of milk constituents, they should think about the change of this trend.

\section{Acknowledgements}

The study was performed during the realization of the project MLIEKO 26220220098 funded by the Operational Program for Research and Development of the European Regional Development Fund. Thanks are due to the Breeding Services of the Slovak Republic for making the data from milk performance testing available.

\section{Utjecaj stadija laktacije na dnevnu proizvodnju mlijeka, udjele mliječne masti i bjelančevina u ovaca pasmine cigaja $i$ Valachian}

\section{Sažetak}

Svrha ovog istraživanja bila je analizirati utjecaj stadija laktacije na dnevnu proizvodnju mlijeka, udjele mliječne masti i bjelančevina u ovaca pasmine cigaja i Valachian. Laktacijske krivulje za dnevnu proizvodnju mlijeka, mliječne masti i bjelančevina modelirane su kao pod-model životinjskog modela (za 3 svojstva) temeljenog na testnim mjerenjima koje su prikupljene od uzgojne službe Republike Slovačke između 1995. i 2010. Ukupno je analizirano 188.403 podataka (za cigaja pasminu) i 352.094 podataka (za Valachian pasminu). Podaci o karakteristikama mliječnosti uzeti su za ukupno 35.484 ovaca pasmine cigaja, i 66.994 ovaca pasmine Valachian. Fiksni dio modela uključivao je redni broj laktacije, veličinu legla i stadij laktacije. Učinak stadija laktacije utvrđen je pomoću Ali-Schaeffer laktacijske krivulje. Nasumični dio modela uključuje utjecaj testnog dana, direktni aditivni genetski efekt i trajan utjecaj okoliša na laktaciju. Zbog ograničenog broja dnevnih kontrola u prvom i osmom mjesecu laktacije i sličnih poteškoća u modeliranju osobina mliječnosti u tim fazama laktacije, laktacijske krivulje prikazane su između 30 i 210 dana. Proizvodnja mlijeka prema laktacijskim krivuljama smanjivala se prema kraju laktacije, dok su se koncentracije mliječne masti i proteina povećavale. Tijekom 150-dnevne proizvodnje mlijeka, u obje pasmine je zabilježena gotova jednaka količina mlijeka, te koncentracija mliječne masti i proteina.

Ključne riječi: mliječne ovce, laktacijske krivulje, dnevna proizvodnja mlijeka, udjel mliječne masti i proteina

\section{References}

1. Ali, T.E., Schaeffer, L. (1987): Accounting for covariances among test day milk yields in dairy cows, Canadian Journal of Animal Science 67, 637-644. doi: dx.doi.org/10.4141/cjas87-067

2. Antonič, J., Jackuliaková, L., Uhrinčat', M., Mačuhová, L., Oravcová, M., Tančin, V. (2013): Changes in milk yield and composition after lamb weaning and start of machine milking in dairy ewes, Slovak Journal of Animal Science 46, 93-99.

3. Barać, Z., Mioč, B., Špehar, M. (2012): Utjecaj uzgojnog područja, stadija laktacije i stada na neke odlike mliječnosti paške ovce, Mljekarstvo 62, 35-42.

4. Bilgin, O.C., Esenbuga, N., Davis, M.E. (2010): Comparison of models for describing the lactation curve of Awassi, Morkaraman and Tushin sheep, Archiv Tierzucht 53, 447-456.

5. Cappio-Borlino, A., Portolano, B., Todaro, M., Macciotta, N.P.P., Giaccone, P., Pulina, G. (1997): Lactation curves of Valle del Belice Dairy for yields of milk, fat and protein estimated with test day models, Journal of Dairy Science 80, 3023-3029. doi: dx.doi.org/10.3168/jds.S0022-0302(97)76269-6 
6. Carta, A., Sanna, S.R., Casu, S. (1995): Estimating lactation curves and seasonal effects for milk, fat and protein in Sarda dairy sheep with a test day model, Livestock Production Science 44, 37-44. doi: dx.doi.org/10.1016/0301-6226(95)00051-L

7. Cobby, J.M., Le Du Y.L.P. (1978): On fitting curves to lactation data, Animal Production 26, 127-133. doi: dx.doi.org/10.1017/S0003356100039532

8. Čapistrák, A., Margetín, M., Apolen, D., Špánik, J. (2005): Produkcia a zloženie mlieka bahníc rôznych plemien a ich kríženiek počas dojnej periódy. )Production and composition of milk in ewes of various breeds and their crosses during milking period), Slovak Journal of Animal Science 38, 181-189.

9. El-Saied, U.M, Carriedo, J.A., San Primitivo, F. (1998): Heritability of test day somatic cell counts and its relationship with milk yield and protein percentage in dairy ewes, Journal of Dairy Science 81, 2956-2961. doi: dx.doi.org/10.3168/jds.S0022-0302(98)75858-8

10. Fuertés, J.A., Gonzalo, C., Carriedo, J.A., San Primitivo F. (1998): Parameters of test day milk yield and milk components for dairy ewes, Journal of Dairy Science 81, 1300-1307. doi: dx.doi.org/10.3168/jds.S0022-0302(98)75692-9

11. Gonzalo, C., Carriedo, J.A., San Primitivo, F. (1994): Factors influencing variation of test day milk yield, somatic cell count, fat, and protein in dairy sheep, Journal of Dairy Science 77, 1537-1542. doi: dx.doi.org/10.3168/jds.S0022-0302(94)77094-6

12. Groeneveld, E., Kovač, M., Garcia-Cortes, L.A. (2010): VCE User's Guide and Reference Manual, version 6.0, 2010, 125 p.

13. Guo, Z., Swalve, H.H. (1995): Modelling of the lactation curves as a sub-model in the evaluation of test day records. Proceedings of the Interbull Annual Meeting, Prague, Cuech Republic, September 7-8, 4 p.

14. ICAR (2011): International Agreement of Recording Practices. Guidelines approved by the General Assembly held in Riga, Latvia, June 2010. Int. Committee for Animal Recording, 2011, 485 p.

15. Kominakis, A., Rogdakis, E., Koutsotolis, K. (2002): Genetic aspects of persistency of milk yield in Boutsico dairy sheep, Asian-Australasian Journal of Animal Science 15, 315-320. doi: dx.doi.org/10.5713/ajas.2002.315

16. Komprej, A., Gorjanc, G., Kompan, D., Kovač, M. (2012): Lactation curves for milk yield, fat, and protein content in Slovenian dairy sheep, Czech Journal of Animal Science 57, 231-239.

17. Krupová, Z., Wolfová, M., Wolf, J., Oravcová, M., Margetín M., Peškovičová, D., Krupa, E., Daňo, J. (2009): Economic values for dairy sheep breeds in Slovakia, AsianAustralasian Journal of Animal Science 22, 1693-1702. doi: dx.doi.org/10.5713/ajas.2009.90054

18. Margetín, M., Kališ, M., Čapistrák, A., Špánik, J. (1996): Produkcia a zloženie mlieka kríženiek cigája x suffolk počas dojnej periódy. (Production and composition of milk of Tsigai x Suffolk crosses during milking period), Slovak Journal of Animal Science 29, 105-110.
19. Morant, S., Gnanasakthy, A. (1989): A new approach to the mathematical formulation of lactation curves, Animal Production 49, 151-162. doi: dx.doi.org/10.1017/S000335610003227X

20. Oravcová, M., Groeneveld, E., Kovač, M., Peškovičová, D. Margetín, M. (2005): Estimation of genetic and environmental parameters of milk production traits in Slovak purebred sheep using test day model, Small Ruminant Research 56, 113-120. doi: dx.doi.org/10.1016/j.smallrumres.2004.03.002

21. Oravcová, M., Margetín, M., Peškovičová, D., Daňo, J., Milerski, M., Hetényi, L., Polák, P. (2006): Factors affecting milk yield and ewe's lactation curves estimated with test-day models, Czech Journal of Animal Science 51, 483-490.

22. Oravcová, M., Margetín, M., Peškovičová, D., Daňo, J., Milerski, M., Hetényi, L., Polák, P. (2007): Factors affecting ewe's milk fat and protein content and relationships between milk yield and milk components, Czech Journal of Animal Science 52, 189-198.

23. Oravcová, M., D. Peškovičová. (2008): Genetic and environmental trends for milk production traits in sheep estimated with Test-day model, Asian-Australasian Journal of Animal Science 21, 1088-1096. doi: dx.doi.org/10.5713/ajas.2008.70700

24. Pavic, V., Antunac, N., Mioč, B., Ivankovic, A., Havranek, J.L. (2002): Influence of stage of lactation on the chemical composition and physical properties of sheep milk, Czech Journal of Animal Science 47, 80-84.

25. Peralta-Lailson, M., Trejo-González, A.Á., PedrazaVillagómez, P., Berruecos-Villalobos, J.M., Vasquez, C.G. (2005): Factors affecting milk yield and lactation curve fitting in the Creole sheep of ChiapasMexico, Small Ruminant Research 58, 265-273. doi: dx.doi.org/10.1016/j.smallrumres.2004.11.005

26. Ruiz, R., Oregui, L.M., Herrero, M. (2000): Comparison of models for describing the lactation curve of Latxa sheep and an analysis of factors affecting milk yield, Journal of Dairy Science 83, 2709-2719. doi: dx.doi.org/10.3168/jds.S0022-0302(00)75165-4

27. SAS Institute Inc. 2009. SAS/STAT @ 9.2User's Guide, Second Edition, Cary, NC USA.

28. Tančin, V., Mačuhová, L., Oravcová, M., Uhrinčat, M., Kulinová, K., Roychoudhury, S., Marnet, P.-G. (2011): Milkability assessment of Tsigai, Improved Valachian, Lacaune and FlCrossbred ewes (Tsigai $\times$ Lacaune, Improved Valachian $\times$ Lacaune) throughout lactation, Small Ruminant Research 97, 28-34. doi: dx.doi.org/10.1016/j.smallrumres.2011.01.007

29. Vrdoljak, J., Špehar, M., Pavić, V., Mioč, B., Barać, Z. (2012): Utjecaj okolišnih čimbenika na dnevnu proizvodnju i kemijski sastav mlijeka istarskih ovaca, Mljekarstvo 62, 192-199.

30. Wilmink, J.B.M. (1987): Adjustment of test-day milk, fat and protein yield for age, season and stage of lactation, Livestock Production Science 16, 335-348. doi: dx.doi.org/10.1016/0301-6226(87)90003-0

31. Wood, P.D.P. (1967): Algebraic model of the lactation curve in cattle, Nature 216, 164-165. doi: dx.doi.org/10.1038/216164a0 